\title{
Regional Innovation System And Local Economic Development In Indonesia
}

\author{
Adiwan F. Aritenang1
}

\begin{abstract}
In Indonesia, decentralization and globalization has introduced a new spirit for localism. Since decentralisation, regions have been motivated to accelerate economic development through local endowment and resources. The democratic Indonesia government has been interested to follow economy theories and case studies develop in the advance countries. Over the years, government policies have supported and strengthen technology development through industrial clusters and national and regional innovation systems. This research aims to explore current progress of Indonesia innovation system through industrial clusters. The research found the presence of industry clustering and very limited innovation system in Indonesia. The research argues that these activities has significant impact on employment growth, but does not increase the industry's value added.
\end{abstract}

Keywords: $\quad$ Regional Innovation System; Clusters; Local Development

\section{Introduction}

In respond to current globalization and knowledge-based society, countries should be prepared to improve its knowledge and intellectual stock. Throughout the New Order regime (1966-1997), local economic development was neglected and undermined by economic system controlled by the state. Together with the emergence of globalization, Indonesia decentralization has provides new ways for local development. Learning from advance countries, innovation system should be established as the grand design for innovation-based development.

The concept of national innovation system (NIS) were developed in the 1980s and followed by discussion on RISs since the 1990s. The discussion over the years has been limited on theoretical and concepts of innovation policies, as Chung (2002) argues. The NIS can be referred as all interrelated institutional actors that create, diffuse, and exploit innovations including governments, state research and development (R\&D) institutions, universities, and private institutions. As a system approach, NIS provides trust and lowered the level of risk among innovation actors through communication and knowledge sharing, in which innovation and accumulation of know-how could be enhanced. There has been a paradigm shifts on innovation from linear sequential perspectives to dynamic and interactive-recursive model, the ever growing importance of actor interactions and social learning, and balanced development policy between national-regional levels (Taufik, 2007). With this background, the national innovation system (NIS) has been studied along with its regional counterpart. Researchers also have acknowledged the importance of regional

\footnotetext{
${ }^{1}$ Agency for Assessment and Application of Technology

Jl. M.H. Thamrin No.8 Jakarta, Tel (62-21) 3169491
}

Korespondensi: e-mail: a.aritenang@gmail.com 
innovation systems and draw its attention to innovation activities in the regions (Braczyk, 1998; De La Mothe and Paquet, 1998; Chung, 2002; Santos, 2007; and Thomas, 2000). This has also been supported with recent debate in the geo-politics studies with introduction of state rescaling from the global political economy (Brenner, 2004) that has also accelerate the regionalisation into the innovation discussions.

This paper aims to exploit current innovation in Indonesia at the level and understand the national policies that support regional innovation system. Furthermore, by exploring cluster industries, as centres of innovation and knowledge-transfer, this study overview its impact to regional development. This argument follows the idea that the establishments of diamond clusters will provide competitiveness and competitive advantage (Porter, 1990) and that the specialization of firms in a phase of production are regarded as Marshall's localization economies (Asheim, et al 2010). Specifically for Indonesia, the introduction of decentralization has provided regions to create its local policies and development aims. However, the study of disparities shows that Indonesia's socio-economic remains severe as found by Resosudarmo and Vidyattama (2006) and the presence of disparities between regions and within regions (Akira and Alisyahbana, 2002). Hence, despite the importance RIS and cluster industries in the regions, NIS policies by the central government is crucial to ensure distribution of innovation and knowledge-transfer between regions to prevent further gaps between advance and lagging regions.

This paper is organized as follows: the next section revisits theoretical perspectives on NIS, RIS, and cluster industries, and case studies from advance countries. In the following section the paper explores these concepts implementation in Indonesia perspectives and how it progress over time. The final section addresses research summaries and possible actions to accelerate Indonesia's regional innovation systems.

\section{National and Regional Innovation Systems}

\section{Clusters and Innovation Systems}

In the last decade, regional disparities have been a global issue (Akita and Lukman, 1995; Fujita and Hu, 2001; Rodríguez-Pose and Gill, 2006; Silva, 2005). This severe regional economic disparity is evidence of the failure of Neoclassical economic theories on explaining the economic growth factors. The endogenous growth theory argues that as neoclassical growth theory neglects the human capital and technological level, the theory assumes balance economic growth and convergence as a given condition in the long run. In contrary, the endogenous growth theory emphasises on the role of knowledge production and technological skills that determine regional economic growth. Thus, endogenous growth theory provides an analytical tool to study the factors of different economic growth among regions and nations.

Recently, the emerging economic geography literature (Pike et al., 2006; Coe et al., 2007) views that territorial innovation model (TIM) as a generic name for models of regional innovation, in which institutional dynamic are at the local level playing significant role. In this model there are at least three types of framework, which are the innovation milieu, learning regions, and the California school of thought Innovation milieu refers to an environment, either a building, a part of a city or the whole city, which provides opportunity to generate innovation process. This idea is based on the role of endogenous institutional potential to create innovative dynamic firms. Such idea also found in industrial district (ID), adding with partnership and cooperation among firms involved in the innovative process. Furthermore, Sonn and Park (2011) introduce the notion of vertical and horizontal convergence. This idea is based on spatial-influenced innovation and technology R\&D between different size of cities (vertical convergence) and similar size of cities (horizontal convergence). The research found vertical divergence that increases 
development gaps between large and small cities. While horizontal convergence occurs through labour, capital and institutions.

Another concept is the learning region, which was introduced by Cooke, Morgan, and many others, as an intermediate synthesis in the debate of TIM (Moulert and Sekia, 2003). This approach claims that it summaries and integrate innovation system, institutional-evolutionary economics, learning process, and the regional institutional dynamics. In his paper, Morgan (1997) argues that learning regions is aimed to connect the concept of the network paradigm to the problems of regional development. In detail, Storper (1989) explains that these networks as principal dilemma of geography that are consisted of the traded and untraded inter-dependencies. The views on innovation of representative in TIM based on the definition of innovation, role of institution, views of regional development, views of culture, type of relation among firms, and types of relation between firm and its surrounding. Although there is no explicit convention among views, the author sees that TIM concept as an innovation process in which: capacity of firm to innovate (Innovation Milieu), as an interactive learning (learning regions), and research and development (R\&D) process (NIS). This can be added with a claim that TIM is also a view of innovation as a continuity process of social interaction within a specific location.

On the business studies, cluster industries of business introduced by Porter (1998) defines that clusters as geographical concentration of inter-connected companies, specialized suppliers, service providers, and associated institutions in particular field that compete but also co-operate. In particular, the cluster industries concept provides harmonization of local sectors and actors in regional development. Unlike the TIM concept, the cluster industry concept is less abstract and stylized, with emphasis on real world business interaction. Porter's cluster industry concept focuses on the linkages between elements that include the factor input, demand conditions, firm rivalry and strategies, and supporting agencies. To identify cluster industry, the following characters are the most common:

- Geographical concentration of various size of firms (large, medium and small enterprises) and various industry stages (assembly, wholesale)

- Thick networks of socio-economic relationship across firms and people

- Agglomeration of activities and firms

- There are core players in the vertical-hierarchical clusters and distributed decisionmaking shared in horizontal clusters.

A more recent approach to the innovation concept is the NIS that consists of thick institutional networks of academics, business, and industries and supported by central and regional governments that act as policy makers and coordinator for $\mathrm{R} \& \mathrm{D}$ perspectives and visions. Because regional innovation system performances related with national level, Chung (2002) argues that national innovation system as a matrix of regional and sectoral innovation systems (Table 1). Hence, by developing sectoral innovation system based on its regional competence, the government can establish effective NIS. As innovation relates with national environment and culture of innovation system strategies started at the national level. However with the emergence of localism in advance countries, the regional innovation system became more relevant and crucial to enforce innovation activities at the regional level. The differences in development orientation and vision in local policies has leaded to difference in development aim thus innovation policies also become local specific. 
Based on the literature reviews, the NIS and RIS should be government funding as the main source. Furthermore, the innovation system should also promote mindset change and innovation activities across regions with spatial distribution of knowledge-transfer. The government should also establish policies to activate interaction learning between firms and institutions through formal and non-formal meetings. The innovation system should also be reciprocal networks as research should be beyond regions and through interaction of actors.

Table 1. Actors in RIS and SIS

\begin{tabular}{lcccc}
\hline & Region A & Region B & Region C & \\
\hline Sector 1 & A1 & B1 & C1 & SIS - 1 \\
Sector 2 & A2 & B2 & C2 & SIS - 2 \\
Sector 3 & A3 & B3 & C3 & SIS - 3 \\
& RIS - A & RIS - B & RIS - C & \\
\hline
\end{tabular}

A1-C3 = Actors in Region $\mathrm{X}$ and Sector $\mathrm{Y}$ (universities, public institutions, industries, regional and national government)

Source: Chung (2002)

\section{Innovation Institutions and Governance}

In this section, we will discuss the importance of institutions and governance in innovation activities. As an outcome of an institution, governance has been studied widely to understand its impact on clusters development, survival, and on local development. In the cluster development, governance is recognized in firm networks within cluster. The manufacturing-clusters are often viewed as monopolistic or oligopolistic with one or a few companies polarize inter-firms production exchange of the entire cluster. This is seen in the hierarchical governance where a main firm acts a buyer that gives orders, assembly, and asymmetry bargaining power with its subcontractors. The example of this cluster is the Japan-lead automotive cluster. On the other hand, the Marshallian industrial district with large number of SME at all stages, each have specialization, resulting in an integrated and supplementary production activities. Opposite with the hierarchical-cluster, firms in this cluster are equally power-distributed and shared decision-making.

While in the survival possibilities, governance could determine clusters orientation and continuity. First, governance determines clusters innovation with national and regional policies provided by network of actors including the government, R \& D institutions, business, and academics. Second, governance is important to avoid the "replication effect" in which new creativity and innovation are hindered by the emergence of recycle creativity with the changes of media but the content is the same. Furthermore, the sources of regional innovation are internal capacities and external spillovers. Internal capacities consisted of direct inputs in the research process and the creation of innovation systems in the local environment (Rodriguez-Pose and Crescenzi, 2008, p. 54). At the micro-level, innovative units (R\&D departments within firms, universities, research centres, etc), institutions, individuals interact with each other and external environment through their networks. While the external spillovers are obtain through locals' capacities to attract and assimilate outside innovation. There are no reasons that knowledge spillovers should be constrained by physical barriers such as city, state or national borders (Rordriguez-Pose and Crescenzi, 2008, p. 54; Audretsch and Feldman, 2004, p.6) 
The impact of cluster to regional development is carried out by Florida (2002) that views creativity and knowledge spillovers as the driving force of economic growth and development. While the supporters of system innovation added that innovation as the basic ingratiates for the development and regional competition. The presence of highly skill and creative workers are the success key for economic development of a firms and region. Furthermore, Florida (2002) argues that creativity is the basic of creative industry and creative class within local society. Many authors support this view based on that the local economic development is related with creative and highly skilled human capital, and that the occupation of these human capital are the primary engine of innovation and growth.

The study of regional innovation systems are dominated from developed countries. For example, the Baden-Wattenberg in Germany, which is one of the country's strongest regional economies with GRDP per capita that are 34\% higher than the EU average of 100. The key sectors of this region are automotive, electronic, and mechanical engineering, with the core sector on automotive. Inhabited by leading automotive firms such as DaimlerBenz, Porsche, Audi, Sony, IBM, and Alcatel, the region become an example of tight networks between core industry, suppliers, and supporters of universities, polytechnics, basic and applied research institutes, and technology transfer centres (Cooke, 1996). In addition, innovation studies on this region also reveal the presence of institutional thickness with 13 chamber of commerce and trade and industry promotion, and financial supports.

Another case study from the UK shows that innovations in the country are led by business activities. Overall, there is no custom of innovation models of RIS and the case shows that pursuing "high road" of innovation integration support structure, and the diversity of innovation networks, in which this has been the case for Yorkshire and Humberside (Thomas, 2000). The Strathclyde region creates a culture of innovation with promoting internalization of innovation process in existing companies and focusing on the innovation companies rather than the innovation industries. The common approaches of these regions are the local governments commitment to culture of innovation and entrepreneurship, the upgrade of ICT infrastructure, and identify regional universities as the main sources (Thomas, 2000).

It can be summarised that the basis for innovation networks in the UK are as follows, first, collaborative networks that started with firm-supplier networks, then the interfirms networks and these networks eventually promote inter-firms-supplier networks. Second, the common awareness is to enhance universities' role as the centre of innovation of new technologies and produces "spinouts" for regional companies. Third, the maximum SME take-up of innovation opportunities and enable R \& D through knowledge transfers and emphasis on building blocks for innovation culture among business through business sector innovation networks. Finally, business champions that include manufactures and services providers, suppliers, customs, and supporting agencies lead the block. Thus, this sectoral network was seen to deepen on the capacities of the key escorts to mobilize supporters of the centre to excel. The centres are electronics, medical products, and food industries. Despite its recent introduction, innovation polices in UK regions are expected to have preliminary impacts to the respective regions as it has introduce innovation regional technology discourse and extensive policies networks to establish and reinforce regional innovation strategies.

\section{Indonesian National and Regional Innovation Systems}

\section{National Innovation System in Indonesia}

Indonesia policy direction of Science and Technology are set in the National Midterm Development Plan (NMDP) 2004-2009 as: 
1. To sharpen $R, D, \& E$ priorities (in $S \& T$ ) to be oriented to private sector and society's demand and needs with clear roadmaps.

2. To enhance S\&T capacity and capability by strengthening S\&T institutions, resources and networks at the central and regional level as well.

3. To create innovation climate in terms of the right incentive schemes to foster industrial structure strengthening.

4. To implant and foster S\&T culture to enhance the nation civilization.

With this NMDP, the government promotes National Research Agenda 2006-2009 through the National Research Council (NRC). The legal framework and strategic in the National Research Agenda (NRA) are illustrated below (Figure 1).

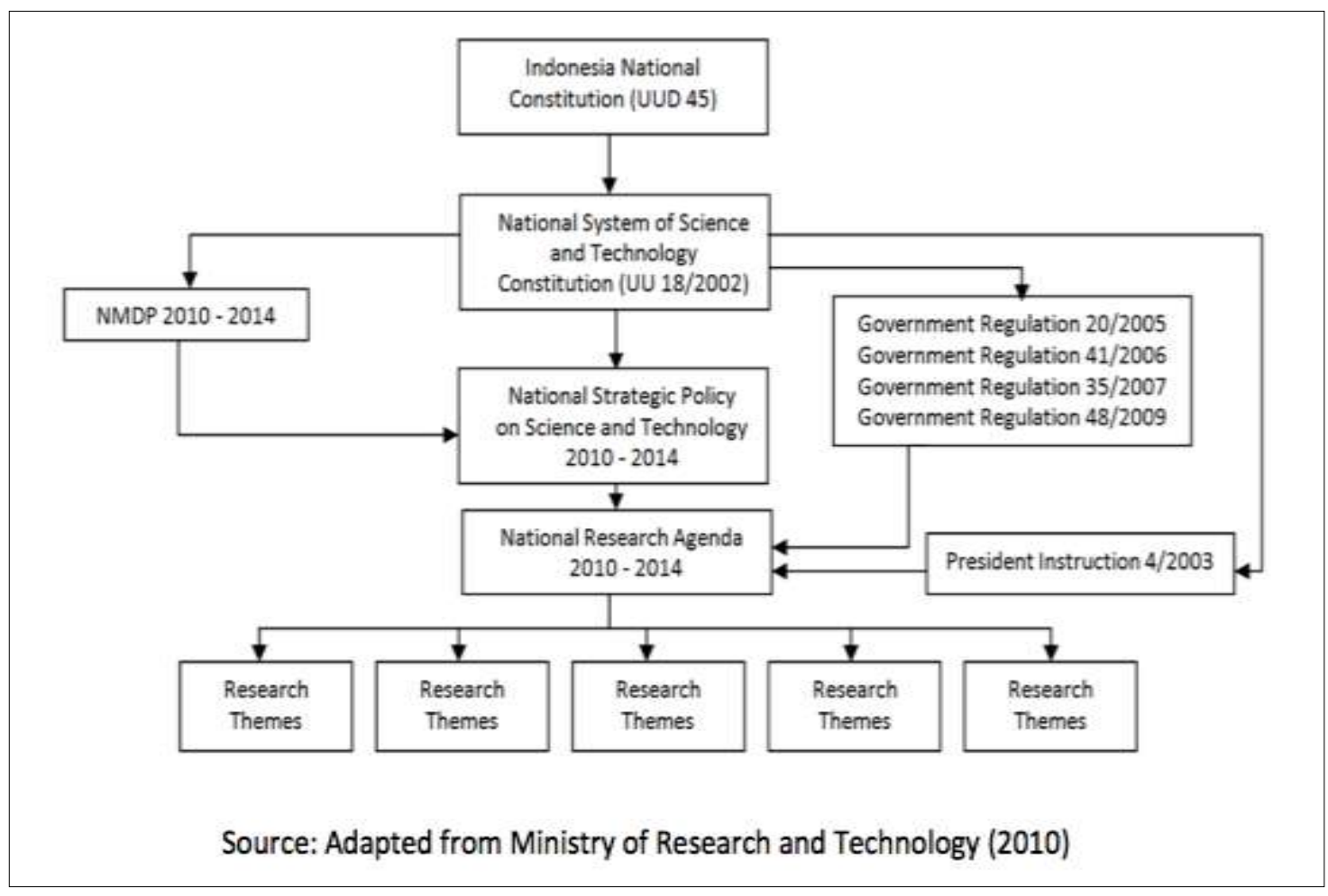

Figure 1. Reference Legal Framework and Strategic Environments in NRA Formulation

The $S \& \mathrm{~T}$ law requires the NRC to advice the government in formulating $S \& T$ development strategic policies. While the $S \& \mathrm{~T}$ law requires the regions established regional research council/RRCs (Dewan Riset Daerah /DRD) to advice and assist regional government in $S \& T$ and innovation system. Presently, there are nineteen provincial RRCs and five RRC-like organizations have been established. However, as Taufik (2007) argues, despite the advancement and readiness of legal documents and research publications, 
Indonesia's innovation has not been a consensus systematic and policy framework. The documents has not provide clear innovation policy framework that integrate stakeholders (sector-wise and region wise). As such, a tangible and coherent national-regional and crosssectoral dimension of innovation system has not present in Indonesia's effort.

The governance of innovation activities is more pronounce with the establishment of 19 RRCs at the provincial level and 5 local agencies that act as RRCs. These regional research centres are guided and advocated by several central technology agencies such as Agency for Assessment and Application of Technology (Badan Pengkajian dan Penerapan Teknologi/BPPT) and Indonesia Institute of Science (Lembaga Ilmu Pengetahuan Indonesia/LIPI) at all development stages including its establishment, visions and aims, local expert recruitments, and networks with local governments. However, field surveys reveals that these local research councils has not act as its purpose, advisory and guide for technology and innovation activities, because of the limited expertise and skill of the members and the unclear relation with the innovation actors (Aritenang, 2006). Furthermore, the lack of innovation activities in Indonesia has contributed to the failure to optimize the RRCs in the regions, as will be discussed in the following section.

\section{Regional Innovation System and Local Economic Development}

Despite hardly any national and regional innovation system are found in Indonesia, the presence of cluster industries could provide an insight to knowledge spillover and technology transfer in Indonesia. The following types of cluster industries are snapshots of Indonesia's industrial district, in which, theoretically, it is considered lack of innovation and knowledge transfer between firms.

The automotive sector is one of the sectors that have gained from cluster industry type approach. The automotive cluster is regarded as case of successful MNE, in which companies from an advance country, such as Japan, dominated hierarchical networks. This cluster model is known as the keiretsu as networks relations follow a hierarchical structure with the parent companies, such as Toyota and Honda, at the top level, followed by Japanese-owned Indonesian companies, Indonesian subcontractors within the cluster sector, and those outside the cluster (Irawati, 2010). However, it should be noted two characteristics of this cluster model, which are first, the model reduced the work of unintended knowledge spillovers to outside the cluster as companies are encourage to work within its respective keiretsu cluster. Second, the hierarchical structure introduces shared sense of identity, norms, and values within the keiretsu. Thus, tacit knowledge of knowledge spillovers and technological transfers can be more effective through this shared social reference (Amin and Cohendat, 2004).

Another case is the rural cluster of metal casting in Ceper, Klaten in Central Java. The study by Sato (2000) shows that there is no evidence of clusters impacts to industry's development with orientation towards integration without specialization and a wide product range by each firm. The author argues clusters small effect is as a result of strategies for independence, internal integration and limited linkages between firms. This is possible due to District of Ceper's strategic location and high accessibility to dense transportation and transaction to wider economic market, in addition to its historical reputation that enables path dependent.

Batam Island manufacture cluster industries are considered on the assembly licence level with emphasis on product construction and low product development, which requires unskilled and semi-skilled labours. The following graph describes Batam's manufacture level compared with foreign country's industry development. The graph (Fig. 1) shows the manufacturing industries levels with the first box describing the research and development level which Japan and Western countries dominate. While the second and third box are the 
technology development and product integration that East Asia countries are at focusing such as South Korea, Taiwan, and Singapore. While the assembly licence location are dominated by export processing zones (EPZ) and free trade zones (FTZ) including Batam, Johor in Malaysia and Subic in The Philippines.

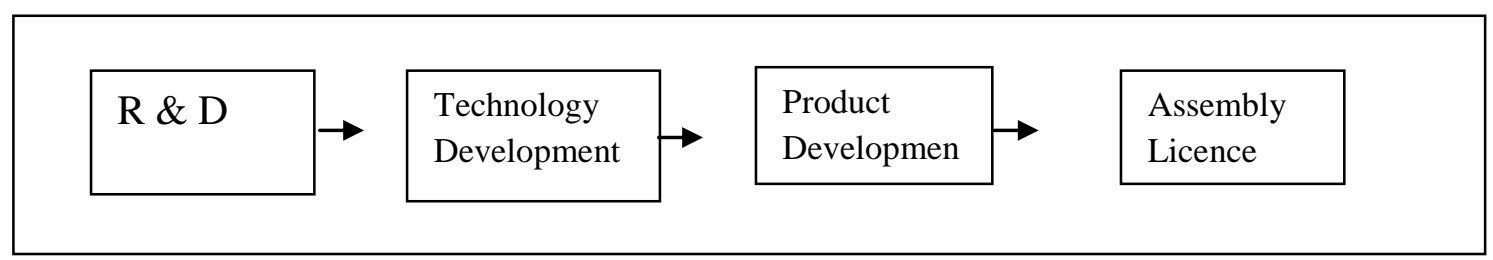

Source: Aritenang (2003)

Figure 2. Manufacturing Advancement Phases

From the case studies above, Indonesian national and innovation system can be seen as follows, first, limited understandings of policymakers and stakeholders, which renders their capacities in designing strategic policies in innovation. Second, disintegrated innovation system polices and efforts that leads to gaps between innovation phases among regions and unclear national innovation strategies. Third, poor innovation system database and indicators to monitor, assess, and evaluate as feedback from policies.

\section{Problems and Strategies}

Examining innovation strategies in Indonesia, we can draw several weakness and problems that presently occurs. The first weakness is inadequate policies in innovation strategies, such as poor innovation incentives and overlapping policies. As Cooke (1996) argues, the question is not whether there should be done, but how soon and what financial resources need to set up. In Indonesia, the innovation demand has been realized since the decentralization with the creation of innovation and technological laws, especially with the creation of National Innovation Committee (NIC) recently. The NIC constitute of 30 experts with various background including academics, business, researcher, and was established to advice and recommend innovation policies hence it has an executive role in technology policies and decision-making. It will be interesting how this new institution would interact and network with previous technology institutions such as National and Regional Research Councils, Ministry of Research and Technology and its Non Departmental Government Institutions such as Agency for Technology Assessment and Application, and the National Nuclear Agency.

Second, there are weakness in linkages between firms and institutions that leads to weakness in innovation culture. Across Indonesia, there are mismatch of knowledge pool development (supply side) and technological utilization (demand side) (Taufik, 2007). There has been limited development and support for both business and research on technologybased activities amongst actors, information and capacities. Third, globalization has provide the opportunity to open the innovation and knowledge-transfer gates thus to gain from it, local firms and actors have to obey set of policies to openness in trade for each country globally. The trade liberalization is expected to increase FDI that will amplify the flow of goods and capital that in turn, will contribute to economic growth. However, the new political theories claim that there will be lagging countries and regions as gain and benefits of trade liberalization are not equally distributed (Nissanke, 2007). This fact causes income inequality and disparities that will leads to greater disparities in social and morality. 
This means lower education, health budget and infrastructure developments. The outputs are low human capital, lower worker productivity and lower long terms growths. The main issue is not whether to integrate to global economy but how to integrate with a fine foundation and sustainable growth.

From various literatures, the research offers the following innovation strategies within clusters industries, which are:

- Developing regional innovation culture through increase public awareness, reformation on education and $\mathrm{R} \& \mathrm{D}$ institutions and fostering entrepreneurship through start-up companies. The strategies also include the capacities building of government (supply side) and firms (demand side), the presence of regional innovation awards (Taufik, 2007). Furthermore, case studies from the UK show the importance of student entrepreneurship forums such as The National Consortium of University Entrepreneurs (NACUE) ${ }^{2}$.

- The cluster industry main strength is the development stage, which the ideas, elaboration, approach, market research and feedback are found. This stage is very crucial to understand the market and determine the cluster's development orientation. For example, the film cluster of Hollywood invest heavily on this stage and despite this effort, it still do not guaranteed success as only $5-10 \%$ of ideas are selected to be produced and the remaining $90-95 \%$ are loss making.

- A focus on the market is essential for a cluster industry as market's taste and size determine cluster's success. A large domestic market allows innovation to be tested, commercialization and validated feedbacks. The film cluster in Hollywood has a very large domestic market with almost 15,000 cinemas country wide thus revenue abroad is purely profits (De Propis and Hypponen, 2007).

- The presence of alternative media and spillovers products. In the film cluster, the production and distribution cost can be covered through its wide-reaching distribution and exhibition networks such as video, television output, and pre-selling rights (De Propis and Hypponen, 2007).

- The presence of chain of actor networks and activities. While the vertical cluster exhibit the central of cluster, the agents surrounding the core have specialized and specific function supporting the cluster. The fostering and diffusion of innovation with programmes such as financial and non-financial supports, fostering technobusiness based development, and establish open coordination in R \&D and policy coordination (Taufik, 2007). In the UK case, the presence of Angles and venture capitals, in which Angels typically invest their own fund and venture capitalists, who manage the pooled money of others in a professionally-managed fund.

\section{Case Study}

To analyse manufacturing cluster impacts on regional development, this section identify clusters of innovation using Indonesia statistics local manufacturing and labor plant data. The research uses Indonesia's BPS industry classification of ISIC 38 that consist of electricity, manufacturing, and transportation equipment. This research uses this ISIC to represent the high technology and highly innovative industry following other empirical studies (Felsentein, 2002; Kenney and Patton, 2005).

The summary of innovation activities level and regional economic growth in 1993 and 2003 are summarised in the following tables (Table 2 and 3). As expected, in both years numbers of patent and value added level, along with highest GRDP per capita, are

2 http://www.nacue.com/ 
found in Jakarta, followed by West Java, East Java, and Riau provinces. Among the provinces, Riau have the highest concentration industries (LQ) explaining that high-tech manufacturing are highly clustered within the region. These figures show that high-tech industry has positive impact to economic growth. In particular, Riau has the highest cluster and experiences the highest growth on patents and value added rank. The province also gained the highest GRDP per capita growth with industry activities and employment that reached two folds between the two periods.

Table 2. Economic Performance in 1993

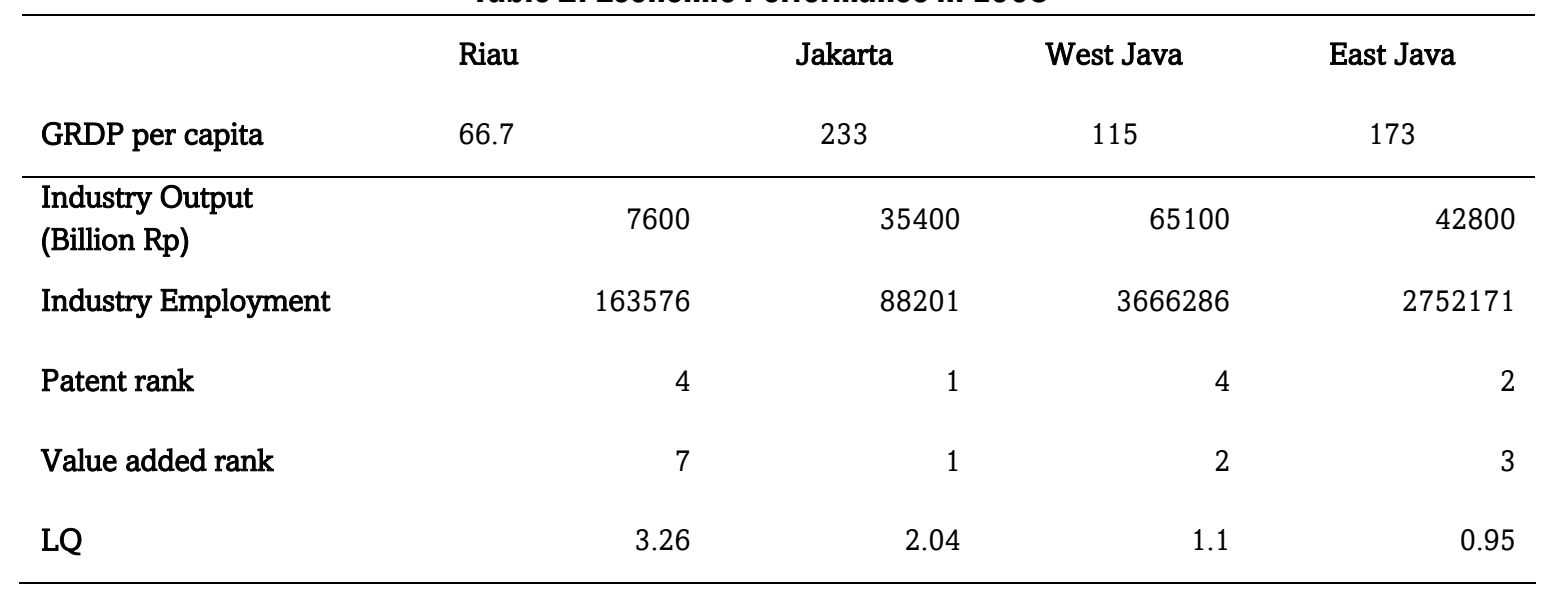

Source: Aritenang (2012), Patent data gathered from the US patent office

Table 3. Economic Performances in 2003

\begin{tabular}{lcccc}
\hline & Riau & Jakarta & West Java & East Java \\
\hline GRDP per capita & 149 & 273 & 153 & 244 \\
Industry Output & 24900 & 46200 & 119000 & 60700 \\
(Billion Rp) & 573762 & 84705 & 6152146 & 3891068 \\
Industry Employment & 4 & 1 & 3 & 4 \\
Patent rank & 4 & 1 & 2 & 3 \\
Value added rank & 2.1 & 1.4 & 1.28 & 0.78 \\
LQ & & & & \\
\hline
\end{tabular}

Source: Aritenang (2012)

To overview the impact of high-tech spatial concentration to regional economic development, the research uses the correlation model following Florida (2002) and Capone (2007). To measure the industry concentration, the paper uses the location quotient (LQ) to overview local specialization within the region or country it is located, as illustrated with the following (Equation 1).

$$
L Q \boldsymbol{\mathbf { F }}^{R_{i t} / R_{t}} N_{i t} / N_{t}
$$


where Rit is the regional employment in industry $\mathrm{i}$ in year $\mathrm{t}$

$\mathrm{R} t$ is the total regional employment in year $\mathrm{t}$

$\mathrm{N}$ it is the national employment in industry $\mathrm{i}$ in year $\mathrm{t}$

$\mathrm{N} t$ is the total national employment in year $\mathrm{t}$

In Table 4 the spatial concentration of this high-tech industry has positive impact for population, employment and manufacturing value added growth. The Figure $3-6$ shows the linkages between industrial activities with regional economic performance. The graphs show that clustering of highly innovation industry significantly increased the number of total employment and industrial worker in the respective industry. However, the industrial clustering contracts population and value added growth (Figure 5 and 6). This finding rejects Florida (2002) argument that clusters of highly innovative industry attracts more employment and population. Furthermore, Figure 6 gives evidence that high innovative industries in Indonesia have low value added growth and this could also be the case in general, as value added and innovation activities in Indonesia remains low.

Table 4. LQ and Population Growth

\begin{tabular}{ccccc}
\hline & $\begin{array}{c}\text { Population } \\
\text { Growth }\end{array}$ & $\begin{array}{c}\text { Employment } \\
\text { Growth }\end{array}$ & $\begin{array}{c}\text { Employment } \\
\text { Growth at 38 }\end{array}$ & $\begin{array}{c}\text { Value added } \\
\text { growth }\end{array}$ \\
\hline LQ & 0.756 & 0.345 & 0.93 & 0.6275 \\
\hline
\end{tabular}

Source: Aritenang (2012)

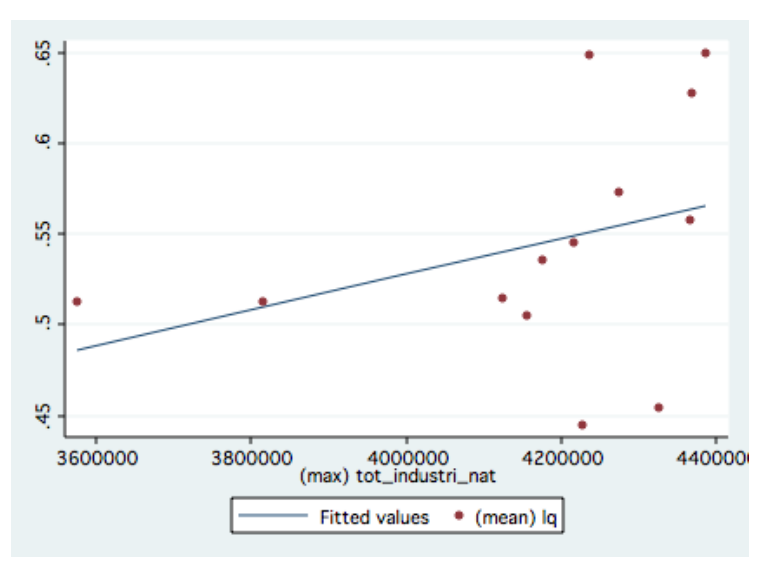

Source: Aritenang(2012)

Figure 3. LQ and Total Employment 


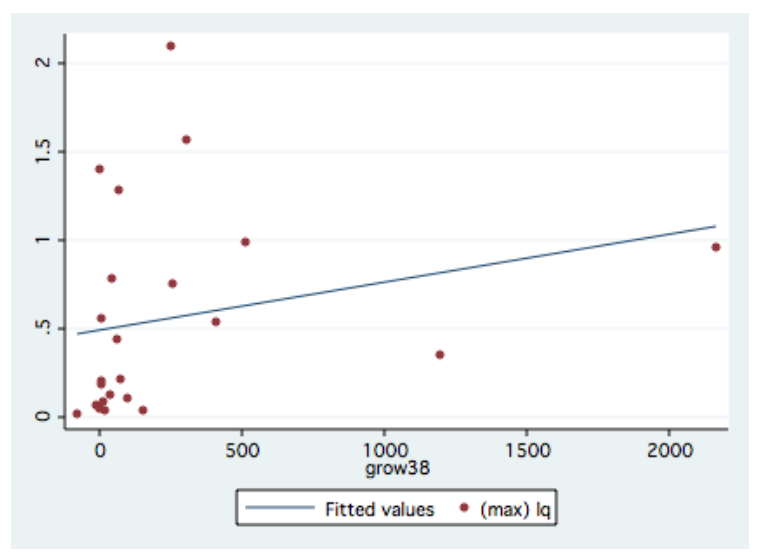

Figure 4. LQ and Employment Growth in ISIC 38

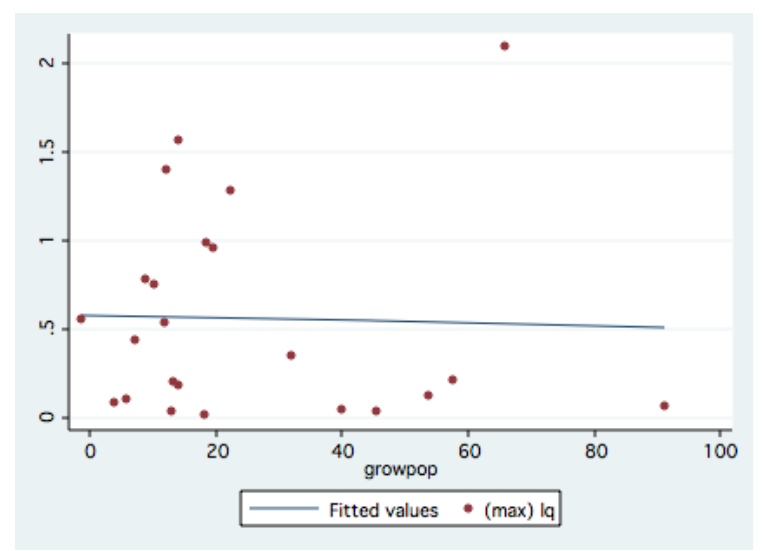

Figure 5. LQ and Population Growth

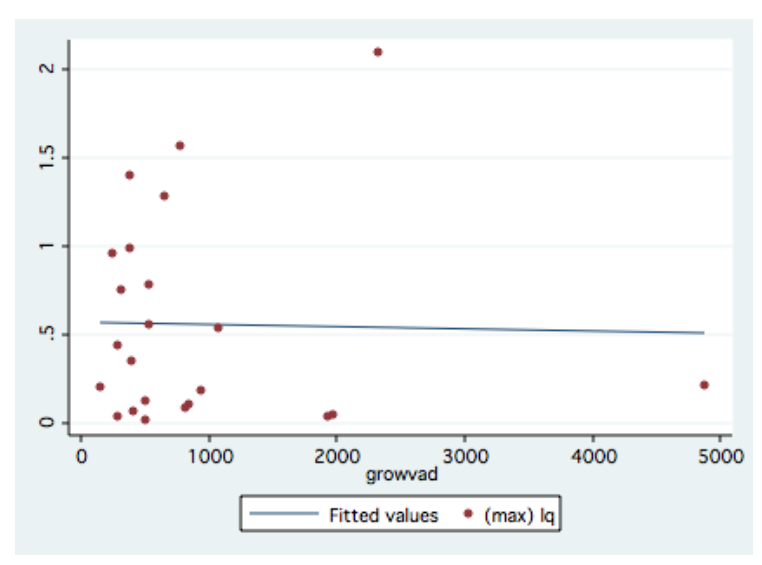


Table 5. Regional Dispersion of Innovation Activities and labour productivity

\begin{tabular}{cccccccc}
\hline \multirow{2}{*}{ Province } & $\begin{array}{c}\text { Number of } \\
\text { Districts }\end{array}$ & \multicolumn{2}{c}{ Industry Innovation ${ }^{1}$} & \multicolumn{2}{c}{ Labor Productivity $^{2}$} & \multicolumn{2}{c}{ Correlation $^{3}$} \\
& & 1993 & 2003 & 1993 & 2003 & 1993 & 2003 \\
\hline Riau & 7 & 0.39 & 0.46 & 1.20 & 0.87 & 0.28 & -0.13 \\
West Java & 25 & 0.40 & 0.81 & 3.66 & 1.72 & -0.12 & 0.31 \\
East Java & 37 & 0.53 & 1.14 & 1.68 & 1.73 & 0.11 & -0.02 \\
Indonesia & 292 & 1.51 & 3.92 & 2.66 & 2.20 & 0.02 & 0.11 \\
\hline
\end{tabular}

Source: Aritenang (2012)

Notes: 1. Coefficient of variation of industrial value added per input

2. Coefficient of variation of GDP per worker

3. Correlation coefficient between spatial distribution of innovation activities and labor productivity

Table 5 above displays the regional dispersion of innovation activities and labor productivity across three selected regions and whole Indonesia. The regional distribution of innovation activities in Indonesia appears to be highly concentrated (coefficient variation $(C V)=3.92$ in 2003) and there has been an increase in regional dispersion significantly since 1993. The highest dispersion (1.14 in 2003) is found in East Java, while Riau and West Java has the highest spatial concentration of innovation activity (around $0.46-0.81$ ).

While the degree of labor productivity dispersion is lower than that of innovation activities. At the country level, productivity rate across Indonesia regions has a weak convergence (from 2.66 in 1993 to 2.2 in 2003). The regions figures show again, that East Java has the highest degree of dispersion (1.73) while Riau shows the highest concentrated productivity (0.87). The last two columns provide the degree of association between regional distribution of innovation activities and labor productivity. The two events are positively and correlated for Indonesia and West Java province. The correlation has increase from 0.02 in 1993 to 0.11 in 2003 . However, there are no constant association within the regions explaining the limitation of industrial innovation in Indonesia and that labor productivity increase is due to imported technologies, rather than a result of local innovation.

If we compared with advance countries, both innovation activities and labor productivity in Indonesia are more dispersed across regions (Table 6). This shows that Indonesia's regions have a heterogeneous regional economic structure. The figures also indicate that clusters of innovation activities and labor productivity in Indonesia are limited in several regions, especially in regions included in this paper. The correlation figures display that there are insignificant positive linkages between innovation activities and labor productivity. In her seminal book, Thelen (2004) argues that institutions that have embedded in a particular country/region influence the level of economic development and growth. In this sense, advance countries such as France, Italy and UK, relies on innovation 
activities to accelerate labor productivity, with correlation between $0.60-0.76$. The opposite correlation is found in German with a negative correlation as the labor productivity is enhanced through by vocational training rather than innovation R \& D (Thelen, 2004).

Table 6

Advance Country's Dispersion of Innovation Activities and labour productivity

\begin{tabular}{cccc}
\hline & $\begin{array}{c}\text { Innovation } \\
\text { Activity } \\
1990\end{array}$ & $\begin{array}{c}\text { Labor } \\
\text { Productivity }\end{array}$ & Correlation \\
& 1.51 & 1990 & 1990 \\
\hline Indonesia & 0.51 & 2.66 & 0.02 \\
Germany & 0.77 & 0.12 & -0.04 \\
France & 1.02 & 0.11 & 0.76 \\
Italy & 0.55 & 0.14 & 0.79 \\
UK & & 0.05 & 0.60 \\
\hline
\end{tabular}

The discussion provides diversity of Indonesia manufacturing distribution activities and cluster industries. The analysis results have confirmed Indonesia's limitation on innovation activities and the presence of cluster industries in selected sector within regions. However, this should not be link directly with the regions' innovation and knowledge spillovers levels. Regions with high concentration and clustered manufacturing does not necessarily meant to have dense innovation and research activities, rather it shows more firms in the respective industry.

\section{Conclusion}

The study elaborates national and regional innovation systems development and obstacles in Indonesia. The empirical study provides insight that the spatial distributions of activities dispersed with the cluster industries in the main industry regions. However, clusters have low industrial value added impact and limited linkage with innovation activities. Nevertheless, polices and regulation of innovation systems and cluster industries are widely implemented in Indonesia. The introduction of decentralization has increase awareness on the importance of innovation for local knowledge and technology based development.

The study identified several weakness and possible steps to improve Indonesia innovation strategies. As with other economy sectors in Indonesia, the technology and innovation sectors has been heavily regulated with many policies and institutions. The recent introduction of National Innovation Committee (NIC) has dense the institutions that has executive and non-executive roles in Indonesia's technology sectors including Ministry of Research and Technology, the technology agencies, and the National and regional research councils. Following Carpenter and Chadwick (2007), the study of innovation in Indonesia should analyse the absorption capacities and innovation outcomes through statistical methods. The absorption capacities should include data on human capital, knowledge sources and networks, and geographical networks among firms/actors. The innovation outcomes are measured through the development of new products, ongoing innovation projects, and the level of social networking and R \& D. However, the required statistics data are yet to be available presently and thus, specific and detail surveys need to be carried out for this study.

There are two policy implications drawn from this paper. First, there should be clear esponsibilities of each public institution to support technology development in the 
industries, universities and research institutions. For instance, while The Ministry of Research and Technology should establish innovation system policies, the agencies should be the frontier institution in research and development (R \& D) and the advisory institutions (NRC, RRCs, and NIC) as the technical and policy advisors. Second, the importance of governance policies in innovation system that requires political will from the government to ensure the innovation culture within the country and regions. A study by Santoso et al (2012) provides an analytical tool for the innovation and technology policy institution such as the Ministry of Research and Technology to overview the current level of technology R\&D and direct future agenda. Adopting from NASA's Technology Readiness Level (TRL) (Mankins, 1995), the study explores the technology R\&D level in the Java Island on six provinces. The research argues that research collaboration and market creation will accelerate the innovation and technology R\&D.

\section{References}

Akira, T., and Alisjahbana, A.S., 2002, Regional Income Inequality in Indonesia and the Initial Impact of the Economic Crisis. Bulletin of Indonesian Economic Studies 38 (2), pp. 201-222

Akita, T. \& Lukman, R., 1995. InterInequalities in Indonesia: A Sectoral Decomposition Analysis for 1975--92. Bulletin of Indonesian Economic Studies, 31(2), pp.61-81.

Amin, A., and Cohendet, P., 2004, Architecture of knowledge, firms, capabilities, and communities. Oxford: Oxford University Press

Aritenang, A.F., 2006, Kerangka dan Instrumen Kebijakan, Panduan Penyusunan Strategi Inovasi Daerah, Taufik, T.A dan Ign.Subagjo (eds), P2KT PUDPKM-BPPT, Jakarta.

Aritenang, A.F., 2012 The Impact of State Restructuring on Indonesia's Regional Economic Convergence, Unpublished PhD Thesis, Bartlett School of Planning, University College London, UK.

Aritenang, W., 2003, Batam dan Singapura, Bersaing atau Kerjasama? in Menuju Batam yang lebih Cemerlang. Khatana Publisher

Asheim, B., 2010. Clusters and Regional Development: critical reflections and explorations. Routledge.

Audretsch D.B. and Feldman M., 2004, Knowledge Spillovers and the Geography of Innovation, in Henderson J.V. and J.F. Thisse (eds.) Handbook of Urban and Regional Economics, Vol.4, pp.2713-2739. Elsevier, Amsterdam

Brenner, N., 2004. New State Spaces: Urban Governance and the Rescaling of Statehood. OUP Oxford.

Braczyk, H., J., Cooke, P., and Heidenreich, M. (Eds.), 1998. Regional Innovation Systems. UCL Press, London.

Capone, F., 2007, Mapping and Analyzing Creative Systems in Italy in Creative Cities in Cultural Clusters and Local Economic Development (Eds. Cooke, P. \& Lazzeretti, L.). Edward Elgar Publishing.

Carpenter, J., and Chadwick, A., 2008, Absorptive capacitiy and innovation outcomes in GB Business: Initial Findings in Path Dependence and the Evolution of City regional Economies (Eds. Simmie, J. and Carpenter, J.). London, NESTA.

Chung, S., 2002. Building a national innovation system through regional innovation systems. Technovation, 22(8), 485-491.

Coe, N.; Kelly, P.; Yeung, H., 2007, Economic Geography: A Contemporary Introduction. Oxford: Blackwell Publishing.

Cooke, P. 1996, The New Wave of Regional Innovation Networks: Analysis, Characteristics and Strategy. Small Business Economics, 8:1-13 
De La Mothe, Paquet, G. (Eds.), 1998. Local and Regional Systems of Innovation. Kulwer Academic, Dortrecht.

De Propis, L., and Hypponen, L., 2007, Creative clusters and governance: the dominance of the Hollywood film cluster in Creative Cities, Cultural Clusters and Local Economic Development (Eds. Cooke, P. \& Lazzeretti, L.), Edward Elgar Publishing.

Felsentein, D., 2002, Do High technology agglomerations encourage urban sprawl?, Annals of Regional Science, 36, pp. 663-682

Florida, R. (2002). The Rise of the Creative Class: And How it's transforming work, leisure, community and everyday life. New York: Perseus Book Group

Fujita, M. \& Hu, D., 2001. disparity in China 1985-1994: The effects of globalization and economic liberalisation, The Annals of Science, 35(1), pp.3-37.

Gomanee, K., 2002, Innovation and Regional Development: An International Comparative Analysis. Working paper No. 195, Oxford Brookes University.

Irawati, D., 2010, Challenges for the Indonesian Automotive Cluster. RSA Insights, Issue 1 No. 1

Kenney, M., and Patton, D., 2005, Entrepreneurial Geographies: Support Networks in Three High-Technology Industries, Economic Geography, 81 (2), pp. 201-228.

Mankins, J. C., 1995, Technology Readiness Level: A White Paper, Pasadena: Office of Space Access and Technology NASA.

Ministry of Research and Technology, 2010, Agenda Riset Nasional: 2010-2014, Jakarta

Morgan, K., 1997, The learning region: Institutions, innovation and regional renewal. Regional Studies 31 (5), 491-503.

Moulert, F. and Sekia, F., 2003, Territorial innovation models: A critical survey. Regional Studies, 37 (3), pp. 289-302

Nissanke, M, 2007, Pro-Poor Globalization: An Elusive Concept of a Realistic Perspective? An Inaugural lecture, School of Oriental and African Studies, University of London.

Pike, A., Rodríguez-Pose, A., and Tomaney, J., 2006, Local and Regional Development. London, New York: Routledge.

Porter, M., 1990, The Competitive Advantage of Nations, Free Press, New York

Porter, M., 1998, On Competition, Boston, Harvard Business School

Resosudarmo B.P., and Vidyattama,, 2006, Regional Income Disparity in Indonesia: A Panel Data Analysis. ASEAN Economic Bulletin 23 No 1, 31-44

Rodríguez-Pose, Andrés and Crescenzi, Riccardo (2008) Research and development, spillovers, innovation systems, and the genesis of regional growth in Europe. Regional studies, 42 (1). pp. 51-67. ISSN 0034-3404

Rodríguez-Pose, A. \& Gill, N., 2006. "How does trade affect regional disparities?," World Development, Elsevier, vol. 34(7), pages 1201-1222.

Sato, Y., 2000. Linkage Formation by Small Firms: The Case of A Rural Cluster in Indonesia. Bulletin of Indonesian Economic Studies, 36(1), 137-166.

Santos, D., 2007, Innovation and Territory: Which Strategies to Promote Regional Innovation Systems in Portugal?, European Urban and Regional Studies, 7: 147157 ,

Santoso, S., Wibowo, S., Fuad, N.A., Aritenang, A.F., and Suripto, 2012, Informasi Indikator dan Statistik IPTEK: Pengukuran Technology Readiness Level (TRL) Hasil Inovasi, Kementerian Riset dan Teknologi: Jakarta

Silva, J.A., 2005. Devolution and disparities in the Philippines: is there a connection? Environment and Planning C: Government and Policy, 23(3), pp.399 - 417.

Sonn, J.W., and park I.K., 2011, The Increasing Importance of Agglomeration Economies Hidden behind Convergence Geography of Knowledge Production, Urban Studies vol. 48 (10) 2180- 2194 
Storper, M., and Walker, R., 1989, The capitalist imperative: Territory, technology, and industrial growth, Oxford: Blackwell.

Taufik, T., 2007, Indonesia's Sub-national Innovation System Policy and Programmes, Presented at the National Workshop on Subnational Innovation Systems and Technology Capacity Building Policies to Enhance Competitiveness of SMEs, Jakarta

Thelen, K., 2004. How Institutions Evolve: The Political Economy of Skills in Germany, Britain, the United States, and Japan, Cambridge University Press.

Thomas, K., 2000. Creating Regional Cultures of Innovation? The Regional Innovation Strategies in England and Scotland. Regional Studies, 34(2), 190-198. 